\title{
Aspectos Conceituais do Financiamento à Inovação*
}

\author{
Solange Corder \\ Doutora em Política Científica e Tecnológica pelo DPCT/IG/Unicamp, Campinas-SP, e Pesquisadora \\ do Grupo de Estudos sobre a Organização da Pesquisa e Inovação (GEOPI/DPCT/IG/Unicamp) \\ Sergio Salles-Filho \\ Professor Doutor do Departamento de Política Científica e Tecnológica (DPCT/IG/Unicamp), \\ Campinas-SP, e Coordenador do Grupo de Estudos sobre a Organização da Pesquisa e Inovação \\ (GEOPI/DPCT/IG/Unicamp).
}

RESUMO

$\mathrm{O}$ presente artigo trata de questôes relativas aos determinantes do financiamento da inovação. Ele traz tanto uma abordagem conceitual quanto prática. No primeiro plano procura-se, com base nos conceitos de investimento e financiamento, subsídios para se compreender os determinantes da decisão de investimento em geral e em inovação em particular. Discute-se como as variáveis de finance e funding, importantes em todo o circuito financeiro de criação de capital para o investimento, afetam o investimento em inovação. Discutem-se, ainda, as relações entre poupança e investimento, e suas relaçôes com o fomento à inovação. No plano prático, aponta-se como essas questões poderiam ser consideradas para a ampliação da capacidade das políticas de incentivo às atividades de inovação, particularmente em países menos desenvolvidos.

\footnotetext{
* Os autores agradecem os comentários, críticas e sugestões dos pareceristas anônimos e ressaltam que as opiniões expressas neste artigo são de sua inteira responsabilidade.
} 
Palavras-Chave $\quad$ Investimento; Financiamento; Política de Inovação; Finance; Funding

Códigos JEL | O16; O31; O38

\section{ABSTRACT}

This article deals with questions related to financing and investment, focusing the problem of innovation financing at both the conceptual and the practical levels. At first, the paper discusses some concepts that are useful for explaining the necessity of promoting investments in science, technology and innovation. The emphasis is on how the concepts of finance and funding should be considered in order to better understand the process of creating capital to promote investment. At the practical level, the article uses such concepts to discuss policy-making aimed at the activities of innovation, with a special focus on less developed countries.

KeYWORDS I Investiment; Financing; Innovation Policy; Finance; Funding

JEL-CODES I O16; O31; O38

\section{Introdução}

Este artigo propõe-se a recuperar os conceitos fundamentais referentes ao financiamento ao investimento a partir do referencial keynesiano e póskeynesiano. Este referencial é utilizado para promover a discussão, em uma primeira abordagem, da questão do financiamento e do fomento ao desenvolvimento científico e tecnológico e à inovação.

O desafio da inovação é grande e torna-se ainda maior considerando-se a necessidade crescente de recursos e a importância da coordenação no processo alocativo, visando uso adequado e eficiente do capital, principalmente no caso dos países menos desenvolvidos, nos quais a escala de acumulação para o investimento produtivo é, em geral, menor do que nos países mais desenvolvidos. Isto limitaria, em tese, ações "perdulárias" para o investimento 
em ciência, tecnologia e inovação (C,T\&I). Como a própria lógica da promoção da inovação, devido aos níveis de incerteza envolvidos, é baseada em comportamentos mais "perdulários" do que os investimentos produtivos tradicionais (construção de plantas industriais, estradas, portos, máquinas em série, bens de consumo duráveis e não-duráveis, etc.), os países em desenvolvimento, com menor capacidade de mobilização de capital, têm maiores dificuldades para promover e fomentar a inovação.

Pior ainda se, além da baixa capacidade de mobilização de capital para o investimento em C, T\&I, o país tiver restrições financeiras que estrangulem o próprio investimento produtivo tradicional. Restrições de capital e restrições financeiras reduzem drasticamente a capacidade de um país em criar círculos virtuosos de crescimento e desenvolvimento.

A importância do sistema financeiro para a alavancagem de investimentos e para a sustentabilidade das empresas é indiscutível, porém as dificuldades de se coordenar interesses distintos que envolvem o capital financeiro e produtivo é uma questão ainda mais complexa em se tratando de investimentos destinados à inovação tecnológica.

Adicionalmente, as mudanças recentes decorrentes do processo de internacionalização do capital financeiro e sua maior volatilidade têm colocado desafios não menos importantes para os países, principalmente para aqueles que não contam com um mercado financeiro e de capitais expressivo, e para os quais o investimento direto externo e um volume de reservas para saldar compromissos financeiros se fazem cruciais.

De onde vem o capital para o investimento em inovação? Do sistema financeiro convencional? Pelas linhas normais de crédito, muito pouco. Normalmente por meio de linhas especiais, com custos reduzidos e prazos dilatados, quase sempre subsidiadas. Do mercado de capitais? Certamente, mas só onde há mercado de capitais efetivamente desenvolvido. De recursos próprios? Sim, mas quase exclusivamente em empresas de grande porte (econômico e financeiro). De fundos mútuos? Sim, para empresas emergentes, que apresentam expectativas excepcionais de crescimento. De fundos públicos de fomento a C,T\&I? Sim, mas com grande ênfase em pesquisa e desenvolvimento pré-competitiva, em atividades ligadas a organizações públicas de C, T\&I e na forma de subsídios aos investimentos privados os mais variados. De incentivos fiscais? 
Sim, mas com várias restriçôes que variam enormemente de local para local e de governo para governo.

Independentemente de onde vêm os recursos, seja do setor público, seja do setor privado, os mecanismos destinados a financiar investimentos em inovação tecnológica são diferentes daqueles voltados ao financiamento convencional, principalmente por conta dos riscos envolvidos e do tempo de retorno, que tendem a ser maiores do que aqueles normalmente vinculados aos investimentos em modernização ou em expansão de capacidade produtiva em condições de tecnologias preexistentes ou dadas.

Em diversas áreas do conhecimento, a forma de se fazer P\&D e de se realizar inovações, sejam tecnológicas, em serviços, organizacionais ou nos mercados, é muito distinta do passado recente. Parte desta mudança deve-se às alteraçôes no ambiente científico e tecnológico e no ambiente concorrencial, muito mais complexos e marcados pela entrada de novos atores. Por outro lado, a crise financeira dos Estados Nacionais gerou uma forte pressão social frente ao uso dos recursos públicos, forçando a sua reorientação para atividades com fins econômicos e sociais mais prontamente perceptíveis.

São diversas as modalidades de financiamento necessárias a uma economia para incentivar o investimento, a pesquisa, o desenvolvimento e a inovação. ${ }^{1}$ Do ponto de vista desta última, espera-se, com as ações de financiamento, que haja o incremento do conhecimento e de novas possibilidades tecnológicas e que estes, por sua vez, sejam refletidos em novos produtos, novos métodos de produção e novas estruturas financeiras.

Numa concepção dinâmica pode-se dizer que as inovações na esfera tecnológica e financeira devem modificar também as preferências dos consumidores e dos usuários em relação aos próprios instrumentos financeiros, forçando mudanças sistêmicas de forma a se reiniciar o ciclo de inovaçôes.

\footnotetext{
Neste trabalho segue-se a abordagem neo-schumpeteriana (ou evolucionista) que entende o processo inovativo como não-linear e, mais ainda, como um processo que, muitas vezes, não pode ser claramente fragmentado em etapas para fins analíticos, pois estas se confundem ou carecem de uma clara definição devido à complexidade do conhecimento e técnicas envolvidos. Daí a tendência a não se falar exclusivamente em inovação, mas nela como parte de um processo mais amplo que envolve a ciência e a tecnologia. Em seu estudo clássico, Rosenberg (1976), ao tratar das influências recíprocas entre ciência e tecnologia, nega o simplismo das relações hierárquicas e unidirecionais e afirma que a tecnologia influencia a ciência. Segundo ele, ao gerar fenômenos para a ciência explicar e ao estabelecer uma agenda para a ciência (aperfeiçoamento das tecnologias por meio dela), o potencial econômico sinaliza a direção do desenvolvimento científico.

A despeito das dificuldades de se discutir essas etapas em separado ao analisar o processo inovativo, quando se trata do financiamento, é preciso fazer um esforço de compreender as diferentes necessidades financeiras em cada momento do processo inovador e as próprias condições de retorno financeiro, que tendem a ser melhores nas etapas mais avançadas do referido processo.
} 
Dotada de conhecimentos cada vez mais complexos e tácitos, a inovação, principalmente a inovação tecnológica, tem se tornado uma atividade ainda mais cara e mais arriscada do que era no passado recente. Por conta disto e das instabilidades dos resultados e de sua apropriação, investir em inovações exige um novo conceito de financiamento. O funding e o finance assumem importância crítica no financiamento produtivo em geral e no financiamento da inovação em particular. Tanto um quanto outro, como veremos neste artigo, assumem, no financiamento à inovação, características diferentes do investimento produtivo tradicional.

O capital de risco, por exemplo, é um mecanismo que se propõe a financiar inovação e, nesse sentido, diferencia-se dos tradicionais beneficiando empresas emergentes e de base tecnológica (EBTs). ${ }^{2}$ Porém, devido às incertezas e grandes riscos, boa parte dos recursos destinados aos investimentos iniciais dessas empresas ainda têm sido obtidos junto a fontes governamentais, o que revela a importância do setor público e das políticas para fazer frente e incentivar investimentos desta natureza.

Para discutir os assuntos acima apresentados, o artigo está construído em três seções, além desta introdução. Na seção 1 abordam-se algumas questões conceituais referentes ao financiamento que permitem entender o seu papel no investimento. Esses conceitos são fundamentais para a compreensão das necessidades financeiras das empresas e para entender como os diferentes tipos de instrumentos de financiamento e as políticas de incentivo podem ser operacionalizados. Mais especificamente, esta análise conceitual oferece pistas importantes para se pensar o funcionamento e a estrutura do sistema financeiro, foco da seção 2, e sua participação no financiamento à C, T\&I que é o objeto de análise da seção 3 , seguida pela conclusão deste artigo.

\section{Financiamento para o investimento}

A abordagem convencional neoclássica tem uma interpretação sobre o papel das instituições e dos mercados financeiros bastante diferente da abordagem keynesiana e de seus seguidores, dado seu entendimento de que o estágio de desenvolvimento atual do sistema monetário em nada ou muito pouco afetou o comportamento dos agentes financeiros.

2 Para uma discussão sobre o conceito de EBTs ver Pinho et al. (2002) e Gorgulho (1996). 
A chamada "teoria dos fundos emprestáveis", ao retomar a interpretação clássica, reafirma que o crédito limita-se a uma mera transferência da poupança dos agentes superavitários para os agentes deficitários, que se realiza por meio dos intermediários financeiros. Na abordagem clássica, o financiamento do investimento era diretamente identificado com as poupanças individuais o que, segundo Chick (1983 apud Studart, 1999), era plenamente compatível com o estágio de desenvolvimento da época, já que a moeda-mercadoria era o meio de pagamento utilizado.

Mas esse tipo de abordagem não mais é capaz de explicar o funcionamento do sistema financeiro das economias modernas. Hoje, diferentemente, os meios de pagamento são representados prioritariamente pela moeda bancária, e não pela moeda-mercadoria. O crédito, no sistema bancário atual, pode se converter numa mera operação contábil de criação simultânea de um ativo (empréstimo) e um passivo (depósitos) (Studart, 1999).

O estágio de desenvolvimento do sistema monetário e financeiro nos dias de hoje torna praticamente irrealista a tentativa de analisar a relação entre o sistema financeiro e o produtivo a partir de uma teoria baseada na dicotomia clássica entre variáveis monetárias e reais.

A abordagem keynesiana oferece uma visão alternativa para a compreensão da questão do papel do crédito e da poupança nos investimentos produtivos e será adotada neste trabalho. Nesta seção, especificamente, procura-se levantar os pontos tratados na literatura especializada sobre esta questão, sem se aprofundar no debate travado entre as duas correntes do pensamento econômico. Em algumas situações certos comentários comparativos serão realizados a título de ilustração.

\subsection{Relação entre poupança e investimento}

$\mathrm{Na}$ abordagem keynesiana, o investimento consiste na aquisição de ativos de naturezas diversas. Na definição do próprio Keynes, investimento

“(...) designa a compra de um ativo, velho ou novo, por um individuo ou uma empresa. Por vezes, o alcance do termo é limitado à compra de um ativo na Bolsa de Valores. Mas também, falamos, igualmente, de investimentos em 
imóveis, máquinas, estoques de produtos acabados ou não; e, de maneira geral, novo investimento, por oposição a reinvestimento, significa a compra, por aplicação dos rendimentos, de um bem de capital de qualquer espécie. Se considerarmos a venda de um investimento como um investimento negativo, isto é, como um desinvestimento, minha própria definição está de acordo com a de uso popular; visto que as transaçôes ocorridas nos investimentos antigos forçosamente se anulam (...)” (Keynes, 1992:72).

A definição de Keynes para o investimento é praticamente consensual. $\mathrm{O}$ mesmo não se pode dizer quando se trata dos determinantes desse investimento, mais especificamente, quando se quer saber a origem dos recursos que dão impulso aos investimentos.

Segundo o enfoque tradicional, neoclássico, para se gastar é preciso ter acumulado recursos. Mas, para essa corrente, a acumulação capitalista, em condiçōes de concorrência, não se verifica pelo acúmulo de lucros extraordinários das firmas, pois estes têm duração limitada, mas sim pela abstinência de gastos. Da mesma maneira as famílias, se pretendem acumular, devem reduzir seus gastos com consumo, ou seja, devem poupar. Quanto maior a poupança numa economia, maior suas possibilidades de investimento. Ou melhor, para que haja investimentos, é preciso haver poupança disponível. Portanto, é a poupança o fator determinante do investimento.

De fato, numa economia de mercado, pode-se compreender a poupança agregada como parte da renda não gasta em consumo e que deverá ser alocada em ativos gerados e/ou administrados por instituições financeiras ou disponibilizada para investimentos. Mas, na lógica keynesiana, isso não significa que para haver investimentos seja necessário haver poupança disponível.

Para melhor entender essa questão, é preciso retomar o papel dos bancos como agentes criadores de moeda bancária (ou de depósitos), que será melhor realizada na seção 2 deste artigo, pela via do crédito. Basta haver disponibilidade de crédito, por parte dos bancos, e propensão a investir, por parte dos capitalistas, que os investimentos poderão se concretizar. Isso quer dizer que, de acordo com o enfoque keynesiano, a decisão de investimento está fortemente atrelada ao financiamento e não tem, ex ante, relação direta com a poupança, como querem os economistas de tradição neoclássica. 
É bastante conhecida essa discordância entre Keynes e a corrente do mainstream econômico no que diz respeito à igualdade entre investimento e poupança e também ao fator de determinação do investimento. Se para os últimos é a poupança que determina o investimento, para Keynes, ao contrário, é o investimento o determinante da poupança. Melhor dizendo,

"o gasto autônomo, que se constitui em parte através do investimento, determina a demanda agregada e-através do seu efeito sobre a renda, dada a propensão a poupar - gera um volume de poupança equivalente ao investimento, via efeito multiplicador" (Baer, 1993). ${ }^{3}$

A decisão de investir, então, é para Keynes anterior à criação de renda, o que significa que a poupança é determinada, e não determinante do investimento. O investimento, é claro, pode se autofinanciar, o que significa que as empresas vão usar suas poupanças prévias, seus lucros retidos, para fazê-lo. Mas isso, do ponto de vista macroeconômico não é relevante, já que, neste nível, não são as poupanças prévias que importam, mas sim a capacidade ou disponibilidade do sistema bancário gerar crédito para atender à demanda por moeda para realização de gastos autônomos e proporcionar flexibilidade na alavancagem financeira aos empresários. Este aspecto será melhor discutido na seção 2.

A poupança macroeconômica, pode ser definida como a "diferença ex post entre o fluxo de renda e ofluxo de gastos agregados em bens de consumo, ou seja, corresponde ao fluxo de gastos agregados em bens de investimento" ${ }^{4}$ (Costa, 1999:238). É este o conceito de poupança real agregada, uma variável de resultado, uma variável residual decorrente do gasto em investimento. Por definição, há uma identidade contábil entre poupança e investimento (expost).

Para decidir investir na produção, os responsáveis procuram levar em conta a rentabilidade esperada, isto é, se os rendimentos ao longo da vida útil do equipamento superarão os custos do investimento, e as condições de financiamento. Para investir em carteira ${ }^{5}$ são considerados fundamentalmente o preço dos ativos financeiros e a expectativa de sua evolução futura. Não existe ex ante

\footnotetext{
3 A poupança ex post é maior que a poupança ex ante devido ao aumento da renda agregada resultante do gasto autônomo.

4 A poupança microeconômica, por sua vez, corresponde ao saldo ex post composto pela parcela não gasta da renda recebida. É um conceito de estoque e não de fluxo como é o da poupança agregada (Costa, 1999).

5 O investimento em carteira refere-se à forma em que os agentes decidem diferir o seu consumo no tempo (aplicação da poupança) (Baer, 1993).
} 
uma relação direta entre eles quando se trata da decisão de investir, o que significa que as decisões de realizar investimentos produtivos ocorrem de maneira independente dos investimentos em carteira (Davidson, 1978 apud Baer, 1993).

É a taxa de juros que estabelece, de certa forma, uma relação direta entre esses dois mercados. Mas, ainda assim, a função que ela assume é distinta em cada um deles. Segundo Costa (1999), como a renda corrente não financia o investimento, para fazê-lo, o investidor tem de vender seus ativos, principalmente os financeiros, ou obter financiamento. Nesse sentido, o investimento é sensível aos juros.

Enfim, conforme dito acima, a renda ou poder de compra não utilizados na forma de gastos em investimentos são aplicados de várias formas, dentre elas em estoque de ativos financeiros. Conforme ressalta Costa,

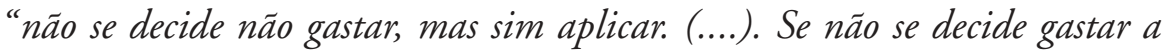
partir do fluxo de renda a ser gerada (ex post), tampouco se decide não gastar a partir desse fluxo de renda não-recebida, mas sim a partir do próprio estoque líquido de riqueza elou do crédito compromissado"(Costa, 1999:238).

Esse conceito de estoque de riqueza conforma a chamada poupança desejada, que representa uma decisão de comprar ativos financeiros como forma de transferência de valor em relação ao tempo. A poupança desejada corresponde ao conceito de propensão a poupar e só será igual ao investimento agregado ao final do processo multiplicador (Carvalho et al., 2001).

Há, portanto, uma poupança real, ex post, que corresponde ao fluxo de renda utilizado no gasto de bens e serviços, e que está associado ao investimento. E há a poupança financeira, que consiste no saldo (estoque) de aplicações das sobras líquidas de recursos em ativos financeiros.

Como a poupança financeira será alocada é que é o ponto central, quando se quer pensar nos investimentos vindouros. A opção por papéis de curto prazo ou de longo prazos, tais como os títulos de propriedade, dependerá da maior ou menor organização dos mercados de ativos, das taxas de juros, ${ }^{6}$ da volatilidade

\footnotetext{
Studart (1999) relembra que, em Keynes, dadas as políticas das autoridades monetárias e do sistema bancário, que determinam a oferta de moeda, a preferência pela liquidez é o principal determinante da taxa de juros. $E$ a preferência pela liquidez varia de acordo as condições de estabilidade dos mercados de ativos. E essa frágil estabilidade é configurada a partir das opiniões divergentes e, uma vez rompida, afeta o desejo de agentes por ativos mais ou menos líquidos e a remuneração pela liquidez. Conforme visto anteriormente, os mercados secundários são importantes para prover liquidez aos ativos e também para reduzir os riscos da subscrição. No entanto,
} 
potencial dos ativos negociados, do nível da fragilidade financeira, da expectativa de retorno, etc.

Segundo Costa (1999), o papel do mercado de capitais não é o de financiar os investimentos, mas sim tornar acessível às empresas a poupança financeira das famílias, que são as aplicações de longo prazo e, com isso, reduzir o endividamento dos investidores junto aos bancos.

\subsection{Finance e funding ${ }^{7}$}

Com base no que foi apresentado até aqui, nota-se que o sistema financeiro, para Keynes e seus seguidores, é bastante complexo e cumpre um papel muito mais decisivo na atividade econômica do que a simples intermediação entre investidores e poupadores sendo assim a instituição elementar em se tratando do processo de acumulação de capital, como também do crescimento e desenvolvimento de economias de mercado.

Como bem observado por Studart (1999), a questão do papel do sistema financeiro no crescimento em Keynes não se esgota na questão da independência do investimento em relação à poupança. Esse papel torna-se mais complexo e mais importante na dinâmica das economias de mercado devido à separação entre as decisões de investir e de poupar e os conseqüentes problemas referentes à compatibilização entre as estruturas ativas e passivas dos diversos agentes envolvidos no processo de intermediação financeira.

Os bancos são capazes de criar crédito (moeda bancária) e financiar os investimentos, independentemente do volume de poupança preexistente (recursos reais). ${ }^{8}$ Porém, esse financiamento inicial do investimento baseia-se em recursos de curto prazo e independe do nível de poupança agregada. O finance, como Keynes denominou essa forma de financiamento, consiste num adian-

\footnotetext{
para que possam cumprir tais funções, é preciso que haja continuidade das transações, de maneira que existam compradores para ativos com preços distintos. A existência de expectativas individuais divergentes e potencialmente voláteis é fundamental não só para garantir as transações, como para a estabilidade dos preços. É neste contexto de instabilidade que é determinada a taxa de juros.

7 Para simplificar a análise, não se está considerando a possibilidade de se tomar recursos no mercado internacional, embora as influências das mudanças no mercado global sejam incorporadas como um dos determinantes das mudanças verificadas nas últimas décadas nos mercados financeiros.

8 Conforme se verá mais adiante, esse financiamento inicial atende às necessidades primeiras do investimento, devendo ser revertidos aos financiadores num curto prazo de tempo.
} 
tamento de crédito de curto prazo aos investidores para a viabilização dos projetos de investimento. 9

"O motivo finance explicita a independência da decisão de investir em relação ao fluxo de renda 'poupado' devido à existência do crédito. Crédito não é poupança” (Costa, 1999:252).

"O finance é concebido como um fundo rotatório (revolving fund) de recursos criados pelo sistema bancário e que não tem sua origem em poupança” (Baer, 1993:26).

Sendo rotatório, deve retornar aos cofres bancários num curto período de tempo, para que não haja uma instabilidade muito forte nas referidas estruturas ativas e passivas dessas instituições.

A empresa endividada pode enfrentar problemas para utilizar recursos próprios como forma de pagamento do que lhe foi adiantado pelo sistema bancário. O fluxo de receitas auferido como resultado do investimento pode, no curto prazo, ser insuficiente para cobrir os custos do crédito (juros e amortizações), obrigando-a a recorrer a novos financiamentos.

Sabe-se que

"o investimento é um compromisso de longo prazo para o empresário, um produto não disponível para o consumo da comunidade e um ativo líquido para a instituição financiadora, quando financiado externamente" (Studart, 1999:160).

As empresas sempre podem recorrer a novas fontes de curto prazo para cumprirem com seus compromissos financeiros, mas os custos de operações desta natureza são bastante elevados e podem comprometer sua saúde financeira.

\footnotetext{
Como mencionado no item 2.1., para realizar investimentos, uma empresa pode se financiar de várias maneiras: pelo uso de recursos próprios ou pela busca de recursos externos, seja por meio da tomada de crédito bancário ou por meio da colocação de títulos e/ou de ativos no mercado de capitais. Considerando-se que a opção foi pela tomada de recursos externos pelo crédito (finance), a empresa poderá cobrir seus custos de produção como o pagamento dos salários, dos bens de capital e das matérias-primas, isto é, poderá efetuar a produção visando obter o retorno financeiro esperado, porém, em geral, num período de tempo maior do que aquele que terá para pagar sua dívida contraída junto ao sistema bancário.
} 
Por isso, é importante que elas possam contar com fontes fornecedoras de recursos cujos custos e prazos sejam compatíveis com os níveis e prazos de retorno esperados.

O mais adequado para o investidor com compromissos financeiros é poder contar com a venda de títulos de dívida (debêntures, por exemplo) ou de títulos de propriedade (ações) no mercado de capitais. Essa operação será bem-sucedida se houver demanda existente por esses ativos. Ela dependerá do tamanho da poupança desejada por ativos de longo prazo, isto é, dependerá da capacidade do sistema de gerar funding e suprir as necessidades financeiras dos empresários.

É neste ponto que se nota uma das maiores dificuldades neste processo dinâmico e permeado por interesses tão distintos. É preciso que haja uma conciliação entre estas decisões independentes, pois, mesmo havendo, em termos agregados, uma equivalência entre a poupança ex post e o investimento - dado o efeito do gasto autônomo sobre a renda, e dada a propensão a poupar -, via efeito multiplicador, as decisões individuais a respeito da forma de manutenção da poupança não têm por que coincidir com as necessidades de recursos de terceiros por parte dos investidores produtivos (Baer, 1993).

Melhor dizendo, a renda gerada via efeito multiplicador dos investimentos - viabilizados ou não pelos recursos bancários (finance) - poderá retornar ao sistema financeiro, via aplicaçóes financeiras de longo prazo. Mas isso poderá não ocorrer por motivos diversos, dentre eles a preferência pela liquidez das famílias ou agentes financeiros.

Para atender às necessidades de funding da empresa, que consistem na transformação do estoque de dívidas herdado do passado em diversas formas de ativos financeiros de longo prazo, as instituições financeiras dependem das aplicaçóes em ativos financeiros de longo prazo. Isso quer dizer que tem de haver uma disposição do público para adquirir tais títulos financeiros de longo prazo ou ações, durante o processo de multiplicação da renda (Carvalho, 1995 apud Costa, 1999).

De acordo com Baer, para se identificar as possibilidades de financiamento de longo prazo, é preciso analisar três aspectos importantes que o influenciam: o padrão de crescimento econômico, o volume de poupança disponível e a escolha mais recorrente dos agentes para a canalização desta poupança. O primeiro aspecto, o padrão de crescimento, é uma decisão política que, mesmo 
passível de sofrer influências externas, é fundamentalmente uma opção feita internamente. $\mathrm{O}$ segundo condicionante não está dissociado do primeiro e diz respeito à distribuição da renda. A poupança agregada, base da formação de funding, será tanto maior quanto melhor for a distribuição de renda e a propensão a poupar dos diferentes grupos sociais. ${ }^{10} \mathrm{O}$ terceiro aspecto, a canalização desta poupança, pode se dar por quatro vias que se combinam de distintas maneiras: a) aplicações individuais ou por meio de fundos de poupança privada em mercados de capitais; b) intermediação de recursos via sistema de crédito privado; c) reinvestimentos dos lucros das próprias empresas; d) fundos de poupança compulsória administrados pelo Estado e canalizados para crédito de longo prazo (Baer, 1993:29).

Os reinvestimentos das empresas são, em geral, sua principal fonte de financiamento de longo prazo. ${ }^{11}$ Nas economias desenvolvidas este tipo de financiamento costuma ser complementado por um intenso desenvolvimento dos mercados de capitais.

Apesar do investimento e a poupança serem independentes do ponto de vista dos agentes individuais, deve haver uma mínima compatibilidade entre o volume global de investimentos para ampliar a capacidade produtiva e as necessidades de financiamento de longo prazo. Em segundo lugar, o volume de poupança agregada também deve ser compatível com sua aplicação visando formar a base do processo de funding. ${ }^{12}$ Encerrar o circuito finance-investimento-poupança-funding não é uma questão simples.

Para compatibilizar os interesses dos investidores e dos poupadores, são necessários ajustes nas taxas de juros e na dinâmica do mercado financeiro. Isso revela o quanto é importante ter um mercado financeiro que funcione adequadamente (Baer, 1993).

Inclusive, se o ambiente capitalista é permeado pela incerteza, é fundamental para que o investimento se efetive, que os empresários estejam otimistas quanto

\footnotetext{
10 Numa sociedade em que a renda se concentra nas mãos de poucos, há uma tendência muito grande em ocorrer uma inversão das decisões políticas e esta tender a se concentrar mais nos donos do capital financeiro deixando pouca margem de manobra para os governos.

11 É o caso dos investimentos em P\&D. Nos Estados Unidos, em 1996,70,9\% do valor executado pelas empresas nesta atividade foram provenientes de recursos próprios, 19,3\% provieram de recursos financiados pelo governo e $9,8 \%$ de recursos captados no exterior (Brito Cruz, 2000:19).

12 Segundo Baer, a qualidade do gasto pode reforçar essas compatibilidades. Os gastos (públicos e privados) devem objetivar, primeiramente, contribuir para o aumento da produtividade das economias, reforçando o processo de geração de renda, seja para aumentar o consumo ou a poupança.
} 
às possibilidades de saldar as suas dívidas, caso tenham que recorrer ao financiamento externo à organização. Da mesma forma, para que as instituições financiadoras tenham disponibilidade para financiar, é preciso que exista certa expectativa de que as empresas serão capazes de consolidar seus passivos de curto prazo. Ou seja, a canalização da poupança desejada para o investimento produtivo não é um movimento óbvio.

Se não houvesse incerteza, o circuito finance-investimento-poupançafunding se completaria simultaneamente ao processo de multiplicação da renda. Mas num mundo incerto, o desenvolvimento completo do multiplicador não garante a alocação da poupança nos títulos de longo prazo ou na compra de ações. Esse papel cabe às instituições e mercados financeiros que têm como desafio a capacidade de diversificar os ativos a serem ofertados às unidades superavitárias e administrar as estruturas passivas e ativas com horizontes de maturação distintos (Studart, 1999).

Conclui-se por ora que, sendo o financiamento o elemento-chave para o crescimento econômico, trata-se de definir a estrutura financeira mais adequada para viabilizá-lo. Na perspectiva keynesiana esta estrutura compóe-se basicamente de um sistema bancário desenvolvido, para o finance, e de mercados organizados de ações, para o funding. Mas, na prática, nem sempre esses dois sistemas estão presentes nessa condiçãao de desenvolvimento e organização, simultaneamente. Inclusive, segundo Zysman, as estruturas financeiras subdividem-se em dois sistemas básicos: sistema com base no mercado de capitais e sistemas com base no crédito (Zysman, 1983 apud Studart, 1999). ${ }^{13}$

No sistema com base no mercado de capitais, a emissão de ações e debêntures de longo prazo é a importante fonte de financiamento da formação de capital. Os instrumentos nos mercados monetários e de capitais são bastante diversificados e há um relacionamento próximo entre as instituições financeiras e as empresas. Nos sistemas baseados no crédito, o mercado de capitais é fraco e as firmas dependem fortemente do crédito para obter recursos além dos lucros retidos; os bancos comerciais dependem das autoridades monetárias, de maneira que o governo influencia os níveis e a direção do investimento privado, e há uma tendência ao rápido aumento do endividamento das firmas investidoras

\footnotetext{
${ }^{13}$ Nos países anglo-saxões, por exemplo, o mecanismo clássico de financiamento engloba sistemas bancários desenvolvidos (provedores de finance) e mercados organizados de ações (provedores de funding), mas em muitos outros países o modelo é distinto, concentrando-se num ou noutro mercado.
} 
nos períodos de boom. Nesse sentido, como coloca Studart, cada tipo de arranjo institucional possui condições de estabilidade financeira que lhe são características. Como destaca o autor, em sistemas baseados no crédito, a estabilidade das taxas de juros nominais de curto prazo é essencial pois, não raramente, as empresas inversoras são obrigadas a rolar continuamente sua dívida sob taxas de juros flutuantes. Por outro lado, o sistema de mercado de capitais é mais sensível a surtos especulativos nos mercados de estoques de ativos (Studart, 1999).

O problema é maior em países nos quais os canais de consolidação financeira não estão plenamente desenvolvidos e que, por conta disso, ou por outros motivos, inexiste propensão do público a adquirir títulos de longo prazo ou ações durante o processo de multiplicação da renda. Neste caso, mecanismos de poupança forçada se fazem necessários. ${ }^{14}$

Ou seja, do ponto de vista institucional, uma economia que não conta com um mercado financeiro organizado e com um mercado de capitais atraente tende a enfrentar problemas para estimular investimentos. Se as famílias, por exemplo, optam pela liquidez de maneira a manter uma parte de sua renda sob a forma líquida (depósitos monetários) e que, por conta deste comportamento reduzemse as possibilidades de funding, retraem-se as decisóes de gasto da economia.

Feita esta argumentação de natureza mais conceitual, procura-se na seção que se segue examinar a conformação do sistema financeiro para melhor compreender seu funcionamento e definir o seu papel na promoção dos investimentos produtivos e, mais especificamente, dos investimentos inovativos, foco de interesse deste trabalho. Esse é mais um passo na tentativa de construir fundamentos sólidos que venham contribuir para a reflexão e a construção de políticas de inovação capazes de aproveitar o potencial já existente das instituiçōes e dos mercados financeiros, e capazes de criar novos instrumentos de financiamento, tendo em consideração os limites deste potencial.

\section{Financiamento: funcionamento e transformações recentes}

O processo de financiamento econômico depende da existência, de um lado, de ofertantes de recursos financeiros e, de outro lado, de demandantes

\footnotetext{
14 No Brasil, o Fundo de Amparo ao Trabalhador (FAT) e os fundos setoriais de infra-estrutura são exemplos de ações compulsórias para canalização de poupança, assim como o BNDES que, como banco de desenvolvimento, visa garantir um fluxo estável de recursos de longo prazo exigido para o financiamento do investimento.
} 
destes recursos. De acordo com o tamanho e a intensidade das operaçôes de mercado, o repasse dos recursos de um agente para outro pode se tornar um processo custoso e demorado e, portanto, tornar-se incompatível com a lógica capitalista de acumulação. As instituições financeiras serviriam para atender aos interesses do sistema econômico, ao intermediar essas relações e reduzir o tempo de circulação do capital.

Essa foi a visão que durante muito tempo predominou entre os economistas para explicar o papel das instituições financeiras, mas a partir de Keynes pôde-se compreender que a atividade de financiamento e crédito dos bancos é muito mais do que uma simples intermediação entre agentes poupadores e prestamistas. Os agentes financeiros não baseiam suas ações no princípio da neutralidade e assumem um papel muito mais complexo e determinante no crescimento econômico e no processo de acumulação de capital do que acreditam os defensores da intermediação. ${ }^{15}$

Segundo Keynes (1992), os bancos comerciais criam moeda seguindo dois processos distintos. O primeiro processo é o de criação primária de depósitos. Nele, o banco passivamente recebe recursos que são depositados voluntariamente por seus proprietários, na forma de papel-moeda ou em cheque que pode ser do mesmo ou de outro banco. O segundo processo consiste na criação ativa de depósitos por parte dos bancos. Esses depósitos correspondem a uma expansão dos ativos bancários que se verifica na forma de investimentos (ativos financeiros, títulos ou outros) ou na forma de adiantamentos (carteira de empréstimos). No caso dos investimentos, os bancos pagam recursos aos agentes.

15 Na visão convencional, ou "visão velha" ou "visão do multiplicador", a intermediação bancária funciona da seguinte maneira: ao receberem os depósitos à vista de um conjunto de indivíduos, os bancos podem repassá-los a terceiros, contando, evidentemente, com a possibilidade dos depositantes originais não resgatarem esse dinheiro de uma só vez ou num prazo muito curto. Uma vez repassados os recursos, sob a forma de empréstimos ou financiamentos, parte desse dinheiro retorna aos bancos, novamente sob a forma de depósitos, e pode ser mais uma vez emprestado a outrem. Essas idas e vindas do dinheiro, adicionadas dos juros cobrados, significam recursos adicionais, isto é, dinheiro que entra no sistema econômico expandindo a base monetária, sem que tenha sido necessária a emissão de moeda.

James Tobin (1971 apud Sarno, 1993) é um crítico dessa visão que, segundo ele, induz a se imaginar que os bancos comerciais têm um poder ilimitado de crescimento, iá que a expansão dos ativos bancários levaria a um retorno automático na forma de depósitos. A atividade bancária criaria condições para seu próprio financiamento, pois as obrigações cresceriam juntamente com os ativos bancários. A limitação seria colocada apenas peals autoridades monetárias por meio da imposição das reservas bancárias.

Para Tobin, ao contrário, os bancos comerciais e as instituições financeiras não bancárias têm a função de atender, em simultâneo, as preferências de porta-fólio dos agentes que emprestam e dos que tomam emprestado. Os bancos são, portanto, agentes intermediários de poupança e não têm poder de criar recursos. Segundo o autor, nem todos os recursos criados pelos bancos na forma de empréstimos retornam como depósitos, podendo ser distribuídos entre as demais alternativas existentes de poupança. A operação dos bancos é, portanto, limitada pelas preferências do público e tem reflexos na esfera macroeconômica (Tobin, 1971, apud Sarno, 1993). 
No caso dos empréstimos, os bancos adiantam recursos aos agentes. Em ambos, os bancos objetivam um ganho ou reembolso desses recursos num momento posterior (Sarno, 1993).

Assim, na visão keynesiana, a intermediação financeira, além de contribuir para a rapidez do processo de circulação do capital, contribui para aumentar o valor dos recursos financeiros em circulação. Esse fenômeno é denominado alavancagem financeira e consiste na criação de novos ativos dessa natureza. ${ }^{16}$

Como esses ativos financeiros influenciarão o processo de geração de renda é uma questão a ser tratada mais adiante. Por ora pode-se dizer que:

"as operaçôes de compra e venda de ativos financeiros não geram renda de forma direta. Geram, sim, poder de compra presente para o agente emissor. A emissão e venda de novos títulos de divida, por parte de agentes que necessitam de dinheiro, aumenta a riqueza financeira existente. Haverá impacto sobre a renda desde que o dinheiro assim obtido seja despendido na aquisição de bens e serviços; a ressalva anterior é importante, uma vez que o objetivo do agente que se endivida pode ser o de saldar dividas anteriores, ou de adquirir ativos financeiros (e não mercadorias). A relação é semelhante no caso de uma ação. Suponhamos que uma empresa que, precisando de recursos adicionais para adquirir novas máquinas e instalaçōes, coloque açôes na Bolsa de Valores. As ações emitidas pela empresa e o dinheiro dos acionistas trocam de mãos, sem que haja geração de renda. Haverá geração de renda no momento em que a empresa pagar seus fornecedores pelas mercadorias adquiridas" (Macedo e Silva, 1999:42).

A despeito da importância dos bancos, as demais instituições que compóem o sistema financeiro também assumem papel importante na atividade financeira de uma economia. É o caso dos mercados de capitais. Nas últimas décadas, o sistema financeiro tornou-se mais complexo, não apenas pelo número de

\footnotetext{
16 Do ponto de vista do tomador, a alavancagem é o endividamento realizado visando obter ganhos superiores ao custo do pagamento da dívida (Carvalho, 1986). Por exemplo, o dinheiro que um correntista aplica num banco é emprestado a outro indivíduo e se transforma num novo depósito bancário. Ocorre, portanto, uma duplicação do valor da poupança original. Outro exemplo é a aquisição, por parte do banco, com o dinheiro do poupador original, de cotas de um fundo qualquer que, por sua vez, usará o dinheiro para comprar ações. Nesse caso, o valor da poupança original pôde ser triplicado e essa mágica de gerar mais valor, sem a agregação de trabalho social, sem qualquer relação com a produção, está na raiz da especulação financeira e na possibilidade do mundo financeiro descolar-se do mundo real (Singer, 2000).
} 
instituições envolvidas, mas também pela diversidade de ativos negociados nos mercados que o compõem. Nos itens que se seguem procurar-se-á apresentar certos aspectos do funcionamento do sistema financeiro e os ativos que são nele transacionados nas chamadas economias de mercado.

\subsection{A escolha dos ativos}

Os ativos correspondem aos elementos que compõem o estoque de riqueza de uma unidade. Alguns desses ativos são mercadorias, ou seja, riqueza originada na produção. Outros ativos, inclusive o dinheiro de uma economia capitalista moderna, não são mercadorias, mas direitos ou riqueza financeira. $\mathrm{O}$ que os diferentes tipos ativos têm em comum é o fato de serem considerados pelos agentes como os meios adequados para a conservação e/ou ampliação de sua riqueza (Macedo \& Silva, 1999). Grosso modo, os tipos de ativos transacionados distinguem o mercado produtivo do mercado financeiro. No primeiro, os ativos correspondem às mercadorias produzidas; no segundo, os papéis ou direitos emitidos. $^{17}$

"Os ativos (financeiros) diferenciam-se pelos riscos que envolvem, pelo perfil de retorno que oferecem, pela complexidade das disposiçôes que regulam o cumprimento das obrigaçōes e pelas garantias que cercam o seu serviço" (Carvalho et al., 2001:240).

Cada classe de ativo é negociada num mercado específico.

Para a composição do porta-fólio de ativos, os empresários procuram avaliar a rentabilidade prevista comparando os retornos esperados e o poder de compra que deverá ser temporariamente imobilizado na forma específica do ativo adquirido. As quase rendas correspondem aos fluxos monetários de receita derivados da utilização produtiva do ativo (lucros), de sua posse (juros, dividendos) ou de sua revenda (realização de ganhos de capital). Outro tipo de retorno é o prêmio de liquidez que, segundo Keynes, expressa a "conveniência

\footnotetext{
17 Os mercados caracterizam-se por um conjunto de instituições que, dentre outros elementos, incluem: a periodicidade do mercado, o período da operação, o grau de centralização das operações, eventuais organizações responsáveis pela emissão de normas e pela fiscalização das operações, os agentes que participam das transações (Macedo \& Silva, 1999:118-19).
} 
e a segurança potenciais" advindas da posse de um ativo (Keynes, 1992). A liquidez distribui-se de forma bastante desigual entre os ativos sendo, em situações não inflacionárias, o dinheiro o ativo considerado de liquidez máxima, dada sua aceitação imediata na maioria das situaçôes.

A presença de um ativo no porta-fólio requer um custo de manutenção que varia de ativo para ativo, atuando como um tipo de retorno negativo. Alguns exemplos de custos de manutenção decorrem dos gastos com seguros, custódia, proteção contra depreciação (no caso de ativos fixos), armazenamento, conservação (caso de estoques de mercadorias perecíveis) (Macedo \& Silva, 1999).

Os ativos financeiros são direitos e estão sujeitos à freqüente avaliação, o que significa que no decorrer das transações pode-se ganhar ou perder. $\mathrm{O}$ mesmo ocorre com os ativos produtivos ou ativos reais. Tal como relata Singer, o risco é inerente à vida humana e aos empreendimentos realizados pelos indivíduos ou instituições (Singer, 2000). O que pode variar é a dimensão do risco, dependendo do tipo de ativo ou do contexto no qual ele é transacionado. ${ }^{18}$

Como o sistema financeiro, mais especificamente os bancos, é composto pelos agentes responsáveis pelo crédito e pela liquidez, pode-se dizer que essas funções são interdependentes e ao mesmo tempo conflitantes, pois, em caso de grande preferência pela liquidez, tende a haver uma redução na capacidade do sistema financeiro cumprir uma de suas funções, a de viabilizar o crédito, com possíveis impactos sobre a geração da renda.

"As transações com papéis financiam o gasto, mas não exercem impacto direto sobre a renda e tampouco sobre o emprego. Em certas circunstâncias, o crescimento da riqueza financeira estimula a produção de mercadorias. Em outras dá-se exatamente o contrário: a preferência dos agentes por ativos financeiros em detrimento das mercadorias, pode levar a uma crise econômica - queda na demanda por mercadorias provoca uma diminuição na quantidade produzida e, portanto, no número de trabalhadores empregados pelas empresas" (Macedo \& Silva, 1999:42).

\footnotetext{
18 Por exemplo, o risco tecnológico difere do risco relacionado aos investimentos tradicionais pela própria incerteza que envolve a atividade inovativa, não só com relação a um possível fracasso da nova tecnologia, mas também pela dificuldade de se controlar os rumos da pesquisa e dos seus resultados, pela dificuldade de se obter e de decodificar informações, dentre muitas outras. Mais adiante se voltará a essa questão dos riscos em relação aos investimentos produtivos.
} 
Se as instituições financeiras têm uma posição estratégica dentro do processo de acumulação de capital, não só no aspecto financeiro, mas também produtivo, porque são responsáveis por grande parte dos recursos que virão a financiar os investimentos produtivos de longo prazo,

"é a postura deles e das autoridades econômicas (por meio das políticas monetária e creditícia) frente à demanda de crédito que sancionará ou não a decisão de investimento" (Baer, 1993:36).

Há, portanto, uma questão política envolvida no processo de alocação dos recursos e um importante papel a ser cumprido pelas instituiçōes financeiras no desenvolvimento econômico. Com relação ao

"volume de recursos internamente disponiveis para deslanchar o financiamento de longo prazo de uma economia, a questão crucial está na opção entre privilegiar o consumo ou dar maior ênfase à expansão dos investimentos. Em outras palavras, consiste na opção do padrão de crescimento econômico, que é antes de mais nada uma decisão política. Ainda que esta opção também possa ser influenciada por determinantes externos, a decisão é antes de mais nada interna a cada país e, portanto, uma questão política"19 (Baer, 1993:28).

\section{2. $O$ mercado financeiro}

O mercado financeiro conforma-se pelas transaçōes ocorridas envolvendo a moeda propriamente dita e conta com a presença de agentes tomadores e aplicadores. Uma aplicação de um agente consiste numa dívida assumida por outra parte, sendo que o reconhecimento dessa dívida ocorre por meio de um papel que, uma vez enquadrado nas normas legais que disciplinam o mercado financeiro, assume a condição de papel ou título financeiro.

No sistema econômico coexistem vários "mercados financeiros": de capitais, monetário, cambial, dentre outros. Existe distinção entre eles, porém ao tentar diferenciá-los pode-se incorrer em certo nível de arbitrariedade e parcialidade. Carvalho (1986) tem o cuidado de dizer que as distinções não são excludentes e não formam um conjunto de partes que, somadas, reproduzem o todo.

\footnotetext{
${ }^{19}$ Grifo no original.
} 
Esses mercados "englobam todas as transaçôes que são feitas com obrigações emitidas por agentes deficitários ou por intermediários financeiros que busquem canalizar recursos para eles". Sua regulação realiza-se com base nas instituições e práticas de funcionamento fixadas pelos participantes destas transações e nas instituições do Estado (Carvalho et al., 2001:239).

Analisados os mercados:

a. pela natureza da transação financeira e do contrato resultante, podem ser separados o mercado de crédito do mercado de títulos;

b. pela identidade dos participantes, subdividem-se mercados primários e mercados secundários;

c. pela disponibilidade de informação envolvida na transação e as restrições impostas no tocante à participação dos agentes, diferenciam-se os mercados públicos dos privados;

d. pelos prazos em que os negócios são liquidados, diferenciam-se os mercados à vista; os mercados a termo e a futuro; o mercado de overnight.

O papel exercido pelas instituições financeiras também é outro fator de distinção dos mercados. De maneira geral, encontram-se instituições que cumprem a função de intermediação financeira e aquelas que realizam operações de desintermediação financeira (Carvalho et al., 2001).

O mercado de crédito é aquele no qual as transaçōes se realizam de forma individualizada e as partes que efetuam o empréstimo são identificadas. As operações negociadas geram obrigações que são, em princípio, intransferíveis e não negociáveis. No entanto, mudanças vêm ocorrendo neste mercado nos últimos anos, conforme se verá mais adiante. $\mathrm{O}$ capital de empréstimo negociado neste mercado retorna ao prestamista, seguindo prazos pré-fixados, e o que se espera dessa operação é o pagamento do montante principal adicionado de juros. A aplicação envolvendo esta atividade é denominada de aplicação de renda fixa. A renda fixa

"propicia o rendimento fixado inicialmente, sem que o aplicador sofra qualquer perda ou ganho em decorrência da forma como o seu dinheiro foi administrado por quem o tomou por empréstimo" (Carvalho, 1986:38). 
Nos mercados de títulos as regras são mais genéricas e padronizadas, de maneira que as particularidades das partes contratantes não são consideradas. ${ }^{20}$ Neste mercado são negociados títulos comerciais, títulos de crédito, títulos de dívida, títulos de propriedade. Quando os títulos podem ser negociados em mercados secundários, tornam-se mais líquidos e, de certa forma, mais fáceis de serem convertidos em dinheiro.

Os dois mercados, de crédito e de títulos, envolvem diversos segmentos, cada qual com regras e motivaçôes muitas vezes diferenciadas.

O mercado financeiro abarca ainda, conforme visto acima, o mercado monetário, no qual são negociados papéis de curto e curtíssimo prazo - até três meses, em média - que não estão sujeitos ao risco de capital. ${ }^{21}$ As necessidades de caixa do governo, empresas ou indivíduos, neste referido espaço de tempo, também podem ser atendidas por este mercado (Carvalho, 1986). O valor do papel é resgatado pelo valor de face e não ocorre a venda em mercados secundários (Carvalho et al., 2001).

O mercado de capitais ou de renda variável, por sua vez, é aquele em que são negociados principalmente ações e opções de ações, que são títulos de propriedade e, portanto, parte do capital das empresas. ${ }^{22}$ São negociados também títulos de dívida pública (bônus, apólices de dívida pública, obrigações do Tesouro Nacional - OTNs), notas promissórias, debêntures, etc. Este mercado engloba toda a rede de bolsas de valores e de instituiçóes financeiras (bancos, companhias de investimento e de seguro). Negociando papéis de curta ou de longa duração, neste mercado existe o risco de capital e o preço de um papel no momento de ser colocado à venda pode não ser o mesmo valor no qual foi comprado. Se o possuidor de papéis deste mercado desejar convertê-los em dinheiro antes de sua data de redenção, é possível vendê-los no mercado secundário.

Assim, o mercado de capitais envolve, ainda, as negociações dos mercados futuros e do mercado secundário. A expansão dos mercados secundários tem representado uma alternativa importante de liquidez para os títulos, facilitando

\footnotetext{
${ }^{20}$ Os títulos são documentos que certificam a propriedade de um bem ou de um valor (Sandroni, 1999).

${ }^{21}$ Risco de capital corresponde à variação de valor entre a compra e a venda do papel.

${ }^{22}$ Como é amplamente conhecido, ao adquirir títulos de propriedade, o agente superavitário torna-se sócio do agente deficitário, como resultado do processo de financiamento, e passa a compartilhar dos lucros do empreendimento tal como o empreendedor a quem financiou (Carvalho et al., 2001).
} 
sua negociação no mercado primário, de forma que os títulos passaram a ser uma importante fonte de captação de recursos.

Neste mercado existem riscos distintos daqueles assumidos no mercado de crédito. Há certos custos para a instituição financeira, mas estes variam conforme o contrato. No entanto, os custos de acesso aos mercados de capitais em geral não podem ser assumidos por empresas nascentes ou por empresas com reduzido nível de receitas, pois há um limite mínimo de patrimônio e receitas para poder dele participar.

Os mercados primário e secundário referem-se, respectivamente, à primeira e à segunda operação de compra de um título. Os mercados secundários garantem a negociação contínua de papéis emitidos no passado, mas tal como ressaltam Carvalho et al. (2001) os mercados primários é que contam mais diretamente como fonte de financiamento para o gasto das unidades deficitárias, pois neles são canalizados recursos para essa classe de agentes.

Os mercados secundários, porém, são importantes porque: a) provêem liquidez aos ativos financeiros negociados, o que permite aos investidores financeiros dispor do capital aplicado quando for necessária a referida liquidez; b) tornam o underwriting por parte de instituiçôes especializadas um risco suportável; c) sinalizam preços para possíveis novas emissões por parte de empresas listadas; d) aumentam o fluxo de informações, permitindo aos investidores financeiros avaliarem a rentabilidade prospectiva dos ativos emitidos no mercado primário (Studart, 1999). Maiores comentários sobre o crescimento dos mercados secundários são feitos ao final deste item.

$\mathrm{O}$ fato de serem aceitos no mercado secundário reduz o risco dos ativos e permite aos emissores do papel pagar uma remuneração menor ao comprador.

"Mercados secundários líquidos e organizados contribuem indiretamente para o financiamento da atividade de investimento"(Carvalho et al., 2001:242).

Os mercados públicos e privados, conforme mencionado, diferenciam-se pelo nível de informação disponibilizada aos participantes. Nos mercados públicos, os termos dos contratos são conhecidos e acessíveis a todos e as taxas de juros tendem a ser as mesmas para contratos de natureza equivalente. É o que ocorre nos pregões das bolsas de valores, quando as ofertas de compra e 
venda de ativos são anunciadas aos operadores. Nos mercados privados, as informações contratuais restringem-se aos dois lados envolvidos na transação. Operaçôes deste tipo são conhecidas no mercado financeiro como "operações de balcão" ou over the counter (OTC). Essas operaçōes são importantes no mercado de crédito e no caso de vários derivativos, pois permitem a diferenciação nos critérios de alocação, segundo o cliente, e a personalização das condições contratuais, respectivamente.

Por fim, no mercado à vista, os negócios são liquidados imediatamente ou num prazo de poucos dias. Nos mercados a termo e a futuro, a liquidação dos negócios se verifica num momento posterior. No overnight, o período de negociação varia de um a quatro dias.

Pode-se dizer que o conhecimento dos mercados acima descritos é fundamental para a escolha dos ativos, no momento do investimento. Da mesma maneira para as instituiçõos financeiras, que podem optar em atuar num ou noutro mercado, segundo seus objetivos.

Conforme visto, o custo dos recursos é diretamente afetado, dentre outros fatores, pela possibilidade de que contratos sejam negociados em mercados secundários, isto é, pela possibilidade de liquidez. Da mesma maneira, a segurança do sistema financeiro também depende da maneira como os mercados estão estruturados.

"Espera-se que mercados de crédito se mostrem mais seguros do que mercados de titulos, porque nos primeiros os transacionadores se conhecem melhor do que nos segundos. Em mercados de crédito estabelecem-se relacionamentos de longo prazo entre as partes, o que não ocorre nos mercados de títulos, onde as transaçôes são normalmente anônimas, especialmente se têm lugar em mercados públicos, como bolsas" (Carvalho et al., 2001:244).

Do ponto de vista da intermediação, nas relações financeiras intermediadas a instituição financeira interpõe suas próprias obrigações no processo de canalização de recursos do emprestador último ao tomador último. É o que ocorre nas operações bancárias envolvendo depósitos e empréstimos. Um cliente deposita seu dinheiro no banco e faz, com isso, um empréstimo que 
lhe deve ser retornado quando desejar (depósito à vista) ou em data preestabelecida (depósito a prazo). Neste entremeio, o banco pode usar o depósito deste e dos demais clientes para emprestar a pessoas físicas, jurídicas, assumindo o risco do crédito (risco de default por parte dos tomadores). Uma operação, de certa forma, independe da outra. $\mathrm{O}$ banco deverá honrar os depósitos existentes mesmo que os tomadores dos empréstimos não o façam para com ele.

As operações desintermediadas são aquelas em que o emprestador último retém consigo diretamente obrigações do tomador final. É o caso, por exemplo, dos commercial papers colocados junto ao mercado monetário; dos bônus emitidos por empresas ou governos junto a fundos de pensão; das ações de empresas junto a famílias ou a fundos de investimento. A instituição financeira, então, não assume nenhuma responsabilidade, exceto a de colocar os papéis, ou melhor, a de fazer a corretagem de valores. O risco de crédito recai sobre o emprestador e não sobre a instituição financeira, que apenas promove o encontro entre tomadores e emprestadores.

Há, no entanto, outros tipos de risco envolvidos nas operações desintermediadas. Nas atividades de subscrição de papéis para posterior colocação, a instituição financeira suporta o risco de mercado, isto é, o risco do mercado não absorver os papéis subscritos aos preços esperados pelos intermediários (Carvalho et al., 2001). Outras operações nas quais a instituição financeira absorve algum tipo de risco são aquelas denominadas underwriting straight e underwriting stand-by. Na primeira, a financeira subscreve a totalidade do lançamento, pagando-o diretamente à empresa. Na segunda, a financeira compromete-se a subscrever os títulos não adquiridos pelo público.

Diversas alterações vêm ocorrendo há algum tempo no sistema financeiro, acentuando-se nas últimas duas décadas, relacionadas ao processo inovador pelo qual vem passando o setor financeiro. As inovações ocasionaram mudanças na estrutura do setor e no comportamento dos agentes financeiros, dentre elas o abandono gradual de posturas conservadoras, de baixo risco, em favor de outras mais ousadas, dinâmicas e arriscadas. ${ }^{23}$ Exemplo da mudança

\footnotetext{
${ }^{23}$ A inovação no sistema financeiro corresponde à introdução de novos serviços financeiros e à reformulação dos antigos, trazendo consigo novos tipos de contratos. No Brasil, os diversos tipos de derivativos que emergiram nos anos 1980 ou mesmo a introdução das contas remuneradas na década de 1970 são outros exemplos de inovaçães que ocorreram em função dos novos tempos (Carvalho etal.., 2001).
} 
estrutural foi a emergência de processos de securitização, decorrência da rápida expansão do mercado de títulos para áreas nas quais as relações de crédito predominavam. ${ }^{24}$

Com a securitização, os contratos baseados em informação idiossincrática vêm perdendo espaço para os contratos baseados em informação pública, permitindo aos agentes deficitários captar recursos a um custo muito menor do que o cobrado pelo crédito bancário convencional. Do ponto de vista dos bancos, essa mudança na natureza da informação forçou uma reestruturação de suas ações, que antes estavam basicamente centradas nas atividades de crédito, nas quais eles estabeleciam um relacionamento de longo prazo com os clientes, dispunham de meios de avaliação de projetos e, com base em seus critérios predefinidos, decidiam o locus da aplicação dos recursos. Com a queda do uso do crédito e o crescimento das operaçóes desintermediadas, a concorrência interbancária foi ampliada substancialmente, forçando os bancos a um processo adaptativo e de reorientação.

A chamada universalização dos bancos, a desregulamentação financeira e a manifestação dos investidores institucionais são outros movimentos que se verificam no bojo das transformações do sistema financeiro, mas para o propósito deste artigo, maior atenção será dada à emergência dos investidores institucionais.

\subsection{Os investidores institucionais}

Os investidores institucionais são atores que vêm ganhando lugar de destaque nos mercados financeiros dos países industrializados, com destaque para os países mais desenvolvidos. Nova dinâmica e grande desenvolvimento tem sido a resultante da atuação marcante desses investidores como mobilizadores da liquidez disponível sob a forma de poupança contratual (Freitas, 1998).

\footnotetext{
${ }^{24}$ Securitização é uma derivação de securities, que quer dizer títulos financeiros. A securitização vem, de certa forma, deslocar o processo de tomada de recursos do crédito para o mercado. Isso significa que empresas podem optar pela colocação direta de papéis no mercado, por meio de commercial papers, por exemplo, em vez de recorrer ao banco para tomar crédito. Este processo caracteriza-se como securitização primária. A securitização secundária refere-se ao crédito bancário que são ativos dos bancos e que passam a poder ser negociados nos mercados de títulos e, portanto, a ganhar liquidez. Esses ativos são "empacotados" e transformados em "papéis" que são repassados aos investidores, liberando recursos para as instituições financeiras retomarem o processo de crédito (Carvalho et al., 2001). Configurase, portanto, uma situação em que os tomadores podem ir direto ao mercado, mas os bancos ganham maior liquidez para os seus ativos, o que pode significar uma redução dos custos do crédito, incentivando sua ampliação.
} 
Caracterizados pelo fato de gerenciarem uma grande soma de recursos arrecadada de várias pessoas para um desígnio comum, os investidores institucionais mudaram substancialmente as condições de operação do sistema financeiro e continuarão a mudar (Carvalho et al., 2001). Destacam-se como principais investidores institucionais os fundos de pensão, as companhias seguradoras e os fundos mútuos de investimento.

Os fundos de pensão consistem numa organização que acumula recursos de seus participantes - empregados ou empregadores que poupam em nome de seus funcionários - visando potencializar as possibilidades de aplicação financeira e garantir um fluxo de renda de natureza previdenciária, sejam aposentadorias, sejam pensões, num futuro relativamente distante. A reunião dos recursos e o conhecimento de técnicas financeiras permitem aos fundos de pensão explorar economias de escala na administração do porta-fólio de ativos financeiros e reduzir os custos dos investimentos em ativos primários relativamente aos custos incorridos pela unidade superavitária individual.

As companhias seguradoras operam com os prêmios pagos por seus segurados realizando investimentos que permitam o pagamento de compensação em caso de uma contingência adversa pré-especificada.

Os fundos mútuos de investimento foram criados originalmente nos Estados Unidos para escapar das regulações daquele país que restringiam o pagamento de juros sobre depósitos à vista, nos bancos comerciais, num período de elevada inflação (fim dos anos 1960, 1970 e 1980). Estes fundos adquiriram características bem parecidas com os depósitos à vista, porém com vantagens ao aplicador, pois eram líquidos, transferíveis por cheque e pagavam juros. Essas prerrogativas permitiram que esses fundos se expandissem rapidamente, de maneira que entre 1980 e 1994 o percentual de investimento das famílias norte-americanas passou de $6 \%$ para $28 \% .{ }^{25}$

Como fatores explicativos para o deslocamento da gestão da poupança das famílias às instituições financeiras, isto é, para a institucionalização da poupança, estão, segundo Freitas (1998), o envelhecimento da população, os incentivos fiscais concedidos para a formação de planos privados de previdência complementar e o processo de securitização, que multiplicou os instrumentos

25 The Economist, "Survey of International Banking", 30/4/95 apud Carvalho et al., 2001, p.350. 
financeiros e ampliou a assimetria de informação entre a unidade superavitária individual e os emissores de instrumentos de dívida direta. ${ }^{26}$

A maioria desses modelos institucionais financeiros surgiu nos Estados Unidos. No caso dos fundos de pensão, por exemplo, os reduzidos benefícios oferecidos pelo sistema de previdência pública norte-americano forçou a complementação de renda via previdência privada. Sua generalização veio em resposta às maiores pressōes sobre os sistemas públicos de seguridade social, num contexto de grave crise do welfare state (Freitas, 1998). Nota-se, porém, que os fundos de pensão nos demais países desenvolvidos, embora venham crescendo, ainda ocupam uma posição de baixo destaque no total dos ativos financeiros dos investidores institucionais.

Do ponto de vista das aplicações, a autora aponta que a natureza das atividades dos fundos de pensão tende a exigir a concentração em ativos de longo prazo e maior retorno, além da diversificação das aplicações no caso de instrumentos com retornos imperfeitos ou negativamente correlacionados. Como sugerem as modernas teorias de porta-fólio, a diversificação pode reduzir o risco das diferentes performances de empresas e indústrias individuais, mas não consegue evitar o risco decorrente da má performance da economia, revelando o papel da diversificação internacional para minimizar este tipo de risco (Freitas, 1998).

A responsabilidade na escolha do mix de ativos é bastante grande e é o retorno relativo desses ativos que orienta, em geral, a escolha dos investimentos. Como há grande variação nos níveis de retorno, em âmbito nacional e internacional, há também rápidos ajustamentos do porta-fólio por parte dos gestores destes fundos. Como o volume de recursos mobilizado é muito grande, é imediato o impacto sobre os preços dos ativos. Isso explica o aumento da volatilidade dos mercados e o aumento da sensibilidade aos retornos de curto prazo ocorridos com o crescimento e o predomínio dos investidores institucionais no mercado financeiro.

Essas mudanças verificadas na operação do sistema financeiro, impulsionadas pelos investidores institucionais, revelam que,

\footnotetext{
${ }^{26}$ A autora ressalta um aspecto importante: nos Estados Unidos, os instrumentos de mercado de capitais e os investimentos institucionais são substitutos quase perfeitos no porta-fólio das famílias, o que significa que, com o crescimento da poupança contratual, as famílias têm se retirado do mercado de capitais. Na Alemanha e no Japão, locais onde os mercados são pouco desenvolvidos, os contratos de pensão são substitutos de depósitos bancários, que em geral são de longo prazo. Esta opção pelos investidores institucionais nestes países vem resultando num processo de crescente desintermediação bancária.
} 
"por um lado, em contraste com a acumulação de ativos por famílias, como era comum nos Estados Unidos, ou com a importância da intermediação bancária na maioria dos outros paises, os investidores institucionais impõem uma perspectiva de porta-fólio nas suas aplicações e, por outro, não se contentam, nem de longe, com os retornos mediocres obtidos em depósitos bancários. Assim, em contraste com a demanda de familias por ativos, provavelmente mais estáveis e influenciadas por outros fatores, como, por exemplo, a imagem pública de uma determinada companhia, investidores institucionais devem estar muito mais voltados para fatores mais objetivos, mas também mais voláteis, de mercado, na escolha de sua carteira. Além disso, mudanças nas carteiras de fundos provavelmente terão, por sua importância quantitativa, impacto muito maior sobre o mercado do que a demanda difusa das famílias. Finalmente, a perspectiva de porta-fólio dá maior peso à dimensão da liquidez das aplicaçôes, até pela maior freqüência de reestruturaçôes de carteira. Isto seria de se esperar não apenas pela maior sensibilidade desses fundos, geridos por administradores profissionais, como pela menor importância dos custos de transaçôes incidentes sobre operaçôes de grande valor, como as conduzidas por eles" (Carvalho et al., 2001:351).

Para os autores, a tendência à securitização será reforçada, pois os investidores institucionais deverão preferir a aquisição direta de obrigações dos tomadores finais a ativos criados por intermediários financeiros. Esse comportamento tenderá a restringir a importância dos depósitos e também a reforçar a tendência à transformação dos bancos de sua função comercial tradicional para uma atuação cada vez mais próxima à dos bancos de investimento. As relações entre poupadores e empresas tenderão a ser mais voláteis e sujeitas a flutuações de mercado. Além do desenvolvimento dos mercados secundários para papéis comprados pelos investidores institucionais, a previsão é que também se desenvolvam mais os mercados de derivativos, ambos com o propósito de oferecer formas de se fazer salvaguardas (hedge) contra o grau de iliquidez que caracteriza alguns papéis, possibilitando sua aquisição por investidores institucionais, impedidos por lei de aplicarem recursos em certos tipos de risco.

Para que os efeitos deste processo sejam sentidos no mercado produtivo, será preciso que as empresas estejam dispostas a fornecer informações detalhadas 
sobre seu desempenho e a não diferenciar investidores, enfim, ela terá de agilizar e melhorar a transparência dos resultados. Numa perspectiva otimista, tudo indica que esse movimento poderá beneficiar a transferência de poupança para o setor produtivo, pois as famílias e os investidores encontrarão no mercado de capitais e de títulos alternativas confiáveis para sua poupança que garantam o longo prazo, proporcionem liquidez e ofereçam retornos razoáveis ao longo do tempo (Nóbrega et al., 2000). Nesse sentido, economias com um mercado de capitais tímido poderão alterar este quadro em função do maior interesse dos investidores em fundos de ações.

Conforme mencionado, essa maior complexidade dos instrumentos e dos mercados financeiros tendem a aumentar a já existente dificuldade das famílias escolherem e administrarem seus porta-fólios de aplicações financeiras, de maneira que a opção pelos investidores institucionais tenderá a ser ainda mais reforçada e difundida por todas as naçôes.

Segundo Mendonça de Barros et al. (1999), essa concentração não é de todo ruim, pois ela requer acompanhamento e monitoração no mercado de ações, contrariamente ao tradicional jogo especulativo baseado em manipulação e uso de informação privilegiada.

Conforme visto acima, a perspectiva de se criar horizontes de longo prazo no interior dos mercados de capitais domésticos por conta dos elevados montantes gerenciados por fundos de investimento, tais como os fundos de pensão, deve ser vista com reservas

"de um lado, porque com a emergência e desenvolvimento de uma série de novos produtos financeiros, o financiamento dito de 'longo prazo' nos mercados de capitais contemporâneos não exclui formas sofisticadas de repactuar o que são, na verdade, contratos de curto prazo. E de outro, a previsibilidade e o horizonte temporal de longo prazo das obrigaçôes contratuais dos fundos não garantem, per se, que os recursos acumulados por essas instituiçôes estejam sendo necessariamente aplicados em ativos de longo prazo"(Freitas, 1998:44).

Analisando-se o impacto do deslocamento da poupança individual em direção à poupança institucional no financiamento dos investimentos produtivos, nota-se que não há aumento do nível de poupança corrente, mas sim a 
opção por uma entre várias outras formas de poupança, gerando um aumento da poupança financeira. Isso porque, conforme já convenceu Keynes e seus seguidores, a poupança é o resultado do investimento, e não sua causa. Nesse sentido, sua elevação continuada dependerá dos aumentos dos investimentos. Em síntese, o sentido macroeconômico do conceito de poupança é ex post. Quem financia o gasto capitalista é o recurso financeiro de curto prazo (finance), que retorna ao sistema econômico sob a forma de poupança.

Ocorre, no entanto, que para atender às necessidades de funding de longo prazo, fundamental para a sustentabilidade dos investimentos, pois permite cumprir com os compromissos de longo prazo assumidos pelos investidores produtivos, as formas como a poupança está alocada se fazem importantes.

Cabe acrescentar que o volume e a composição dos ativos financeiros importam, e muito para o processo de financiamento do investimento. Isso significa que a presença dos investidores institucionais e a conseqüente mudança na composição da poupança financeira vem tendo um forte impacto sobre os investimentos produtivos. Se por um lado esse movimento atrai mais recursos para os mercados financeiros, por outro nada garante sua alocação na atividade produtiva, pois este movimento dependerá da competitividade do mercado de capitais ou do produtivo frente às demais opçôes.

$\mathrm{Na}$ seção que se segue discute-se as particularidades dos investimentos em inovação. Embora sumetida à mesma lógica do capital, a atividade inovativa requer uma análise à parte dadas as especificidades que lhe são inerentes, principalmente em termos da intangibilidade dos ativos, das incertezas e dos riscos, o que explica a inadequação da maioria dos instrumentos destinados a financiar os investimentos, quando se trata de financiar atividades que compóem o processo de inovação.

\section{A problemática do financiamento à inovação}

As características de um projeto inovador variam dependendo do tamanho da firma, da infra-estrutura e dos recursos humanos necessários. Também influenciam este projeto o mercado e o segmento de mercado (padróes de concorrência) nos quais a firma está inserida. Outro aspecto é o grau de inovatividade envolvida, ou seja, se é uma inovação mais ou menos radical e se é de produto 
ou de processo. Importa, ainda, se a empresa atua junto a outras firmas e instituições de $\mathrm{P} \& \mathrm{D}$, estabelecendo redes de relacionamento e o grau de atualização do marco regulatório.

A inovação também traz consigo um conjunto de questões relativas à apropriação (que nem sempre é completa) e à efetividade dos mecanismos de proteção (que tende a ser cada vez menor).

Independentemente da complexidade envolvida, o processo de inovação não deve ser entendido como um subsistema especializado, mas sim como uma das forças que formam a atividade econômica como um todo e por isso a discussão a respeito do financiamento à atividade inovativa não pode prescindir do sistema financeiro - e de suas limitações - e do Estado. O sistema financeiro e o investimento à inovação são dois mundos que não podem ser dissociados (OCDE, 1995).

No entanto, o sistema financeiro é, em geral, conservador e opera num horizonte de curto prazo. Nesse sentido, é antiinovador. Conforme aponta Gorgulho,

"o sistema financeiro está sempre disposto a emprestar para quem não precisa porque estas firmas atendem a todos os critérios de análise econômico-financeira e ainda oferecem garantias reais para o caso de inadimplência. Esta forma de análise deixa explícito que o desempenho passado é o melhor indicador para a tomada de decisão. Sob esta forma de análise, as empresas estabelecidas em setores industriais estáveis e maduros são as mais propensas a receberem financiamento" (Gorgulho, 1996:35). ${ }^{27}$

O financiamento externo tende a se concentrar naquelas etapas mais avançadas do processo inovador, quando a incerteza reduziu-se para níveis aceitáveis. ${ }^{28}$ Isso significa que os mecanismos de mercado, em geral, não são suficientes para prover financiamento à inovação tecnológica. Quando estes mecanismos são predominantes, há risco de sub-investimento geral e de uma inadequada seleção de projetos de investimento particulares (OCDE, 1995).

\footnotetext{
27 Há um desentendimento a respeito desta questão, pois o sistema financeiro, por sua vez, reclama da fraca oferta de projetos aptos a serem financiados (OCDE, 1995).

${ }^{28}$ Mesmo no caso do capital de risco, mecanismo elaborado para auxiliar empresas nascentes, há uma tendência dos investidores de maior porte de alocar recursos nas fases finais do processo. A discussão sobre o capital de risco será feita em seguida.
} 
$\mathrm{Na}$ fase inicial do desenvolvimento de um projeto inovador, em que a incerteza é elevada, o investimento é, em geral, financiado com fontes internas de recursos (gastos correntes, investimento empresarial ou autofinanciamento) e deve contar com apoio do governo na forma de subsídios e/ou de redução de impostos. $\mathrm{O}$ incentivo fiscal, porém, tende a favorecer o alto risco, os projetos de larga escala às custas daqueles promovidos pelas menores empresas. Para as empresas de pequeno porte, sem recursos próprios para estas investimentos de alto risco, é fundamental que haja crédito a um custo acessível, isto é, finance oferecido por fontes públicas.

Uma terceira alternativa para as etapas iniciais de um projeto inovador, principalmente para aquelas empresas de menor porte, start-ups, é o capital de risco. Esta é uma modalidade que cada vez mais vem contando com a participação dos grandes capitais financeiros, através dos fundos de investimento, e com o auxílio de gestores de projetos através de contratos. Mas a maior fonte de recursos deve mesmo provir do setor público, pois, como dito acima, os investidores de maior porte preferem as fases posteriores, mais seguras.

É por isso que os governos têm buscado criar diversos instrumentos de financiamento, visando garantir recursos de curto e de longo prazos e, com isso, atender às diferentes necessidades das empresas e instituiçôes de pesquisa, em distintos estágios inovativos.

Nos EUA, por exemplo, é substancial o investimento privado, mas também é grande a participação do Estado no direcionamento dos investimentos de risco. Neste país foram investidos 43,7\% dos US\$ 645,4 bilhões gastos com P\&D por todos os países da OCDE, o equivalente a 2,5\% do PIB total destes países, no ano de 2001. A União Européia foi responsável por 28,1\% deste valor e o Japão por 16,7\% (OCDE, 2002). A maior parte dos gastos com P\&D (63\%) realizados naquele ano foram destinados ao financiamento da P\&D nas empresas. Na média dos países da OCDE, a iniciativa privada respondeu por 69,6\% da P \&D realizada e as organizações do governo e instituições de ensino superior por $27,7 \%$, no mesmo período.

Também foi nos Estados Unidos que a modalidade de risco mais cresceu. Ali, os investidores institucionais (fundos de pensão, seguros, fundações e seguros-saúde), fontes dos recursos de longo prazo, têm papel relevante. Em 2000, o montante de recursos desses investidores alocado em capital de risco foi de 
US \$ 78,96 bilhões num total de US\$ 93,4 bilhôes, uma participação de 84,5\% no total investido. Cabe notar que estes valores sofreram violenta redução por causa do "estouro da bolha das empresas 'pontocom", mas, mesmo no mercado pós-crise, em 2002 o valor investido por este grupo de investidores foi de US\$ 1,65 bilhão, num total de US\$ 2,54 bilhões investidos em risco, ou seja, uma participação de $63,4 \%$, pouco menor que aquela referente ao ano de 1990 (NSF, 2004, cap. 6).

A participação dos recursos governamentais no financiamento aos empreendimentos de risco também se verifica de forma sistemática a partir das Small Business Investment Companies (SBIC), criadas com base no Small Business Administration Act (de 1958). As SBIC já tiveram papel de maior destaque no mercado de risco, dada sua condição privilegiada de receber recursos governamentais através de créditos de longo prazo, por meio da Small Business Administration (SBA), conformando uma estrutura de funding bastante confortável, que lhe permitia uma alavancagem de até cinco vezes o capital próprio de cada companhia.

Atualmente, a participação do governo norte-americano no seu mercado de risco é um pouco menor, mas de certa forma, as SBIC cumpriram seu papel de difundir as práticas de capital de risco no país e de formar a primeira geração de profissionais e desenvolver diversos fundos de capital de risco, alguns dos quais figuram até hoje entre os maiores deste mercado (Gorgulho, 1996).

Embora na maioria dos países europeus o mercado de risco tenha uma dimensão menor, houve um significativo crescimento em anos recentes. $\mathrm{Na}$ França, a partir de 1999 foram criados mecanismos de risco, como os fundos de capital semente (capital-amorçage ou seed money) para financiar projetos de criação de EBTs nas incubadoras das organizaçóes de pesquisa e das universidades. Pelo lado dos investidores, estes são beneficiados pelos incentivos fiscais para aquisição de quotas dos Fundos Mútuos de Investimento em Inovação (FCPI), instrumento criado em 1997, desde que tenham sido qualificadas como inovadoras pela metodologia da ANVAR. ${ }^{29}$ O compromisso é manter as quotas por um período de cinco anos. ${ }^{30}$

29 Os ativos dos FCPI são compostos por investimentos de risco e por ações cotadas de empresas em expansão.

30 No caso brasileiro, a dimensão do mercado de risco ainda é diminuta, mas avanços no aparato institucional e regulatório marcam os primeiros passos deste mercado, assim como a participação da FINEP e do BNDES visando incentivar seu desempenho. 
Ressalta-se que o apoio governamental, o uso de instrumentos fiscais e de crédito subsidiado é permitido pela Organização Mundial do Comércio (OMC) para incentivar a atividade de inovação. Por isso, mesmo com a crise fiscal que afetou a grande maioria dos Estados Nacionais, tem havido uma elevação substancial da participação do setor público no incentivo financeiro e não financeiro, dependendo da nação, a atividades destinadas à geração de conhecimento ( $\mathrm{P} \& \mathrm{D}$, educação superior e software) e no estímulo à produção de bens intensivos em conhecimento, sendo este um dos caminhos para a elaboração de políticas setoriais.

No entanto, a participação do setor privado também tem se feito presente nos casos mais bem sucedidos. Pode-se dizer que o melhor funcionamento do mercado de risco está relacionado ao bom desempenho do mercado de capitais, cujo papel é de grande importância no momento do desinvestimento, quando os investidores vão se desfazer do compromisso e esperam, neste momento, obter elevada rentabilidade. Há outras formas de saída, que não por meio da oferta pública de ações, mas esta tende, nos países com mercados financeiros desenvolvidos, a ser uma das mais importantes do ponto de vista da alocação de funding ao investimento, além de estimular a expansão do mercado de risco ao aumentar as expectativas com relação à liquidez.

No caso do Brasil, o mercado de capitais não tem participação expressiva na estrutura financeira nacional, o que se explica, segundo alguns autores, no fato do sistema ter se apoiado no mercado de crédito e pelas características dos bancos aqui instalados - universais ou múltiplos - que teriam ocupado lugar privilegiado no sistema, dado o conjunto de produtos que podem operar. Por outro lado, a cultura empresarial, restritiva no que diz respeito a expor seus balanços ao conhecimento de terceiros, também teria afetado seu desempenho.

Outro aspecto que caracterizou o mercado de capitais brasileiro (e ainda o caracteriza), é o chamado efeito crowding out, no qual os títulos do governo acabam por deslocar os recursos destinados ao setor produtivo. Isso porque, para a rolagem da dívida pública, o governo lança títulos remunerados por elevadas taxas de juros, atraindo para si os recursos e, inclusive, contribuindo para que haja uma redução dos meios de pagamento em poder do público, com impactos sobre o consumo e a renda. Se por um lado há um efeito em cadeia, pois menores investimentos implicam menor volume de arrecadação 
fiscal e também menos renda para aquisição de títulos públicos, por outro este continua sendo um importante instrumento utilizado pelo governo para a estabilização econômica no Brasil

Independentemente das causas, o que importa é que este mercado nunca teve papel de destaque para a atividade produtiva nacional. Pouco financiou os investimentos e, ao que tudo indica, terá dificuldades para fazê-lo no futuro, principalmente em se tratando de investimentos de alto risco, como os que estão relacionados aos setores intensivos em conhecimento.

Do ponto de vista da relação entre o setor produtivo e o financeiro ou mais especificamente de como os riscos industriais e da atividade inovativa são interpretados pelo mercado financeiro, pode-se dizer que isto depende de condiçôes específicas do projeto; do funcionamento dos mercados e das condições macroeconômicas. $^{31}$

Mais do que entender o aspecto de como os investidores se organizam para efetuar seus investimentos a partir da sua avaliação dos riscos é saber que o governo pode interferir e influenciar o contexto de gerenciamento do risco produtivo. Ele pode:

- assumir completamente certos riscos produtivos rejeitados pelos investidores privados;

- oferecer garantias de empréstimos, reduzindo o risco de insolvência do prestamista;

- assumir parte do risco do investidor, qualquer que seja a forma que ele possa tomar;

- subsidiar ou reduzir as taxas de juros, encurtando o tempo necessário para o investimento produzir um retorno. Fazendo isso, ele reduz a perda de capital ou o risco de insolvência que aumenta com o tempo;

- assumir, por meio de parceria público-privada, como parceiro no controle de uma operação de investidores, influenciar o modo pelo qual os investidores privados percebem o risco, mesmo que não lhes ofereça garantias formais.

- atuar como acionista, com recursos provenientes de impostos e, em tese, agindo em defesa do interesse do contribuinte (taxpayer-mandated

${ }^{31}$ Para maiores detalhes sobre esta relação entre riscos produtivos e riscos financeiros, ver OCDE (1995:36). 
investment). Neste tipo de investimento, a parte que tem o mandato, isto é, o governo, tem quase que a última palavra na avaliação do risco (OCDE, 1995).

Assim, o alto grau de incerteza e risco que envolve o financiamento à inovação requer algum tipo de arranjo estatal e inclusive de mecanismos de funding compulsório, principalmente quando não se dispõe de mercados de capitais desenvolvidos. Mesmo países que dispõem de sistemas financeiros apoiados em mercados de capitais bem estruturados, e com os quais as empresas podem contar para seus investimentos em inovação, não se limitam a este sistema, contando um pesado funding público em setores específicos como o aeroespacial, eletrônico, automotivo, defesa (Bastos, 2003). É o que acontece com a economia norte-americana e também nas demais economias desenvolvidas da OCDE.

Ainda na esfera do apoio público podem ser mencionados outros mecanismos, tais como os incentivos fiscais, o fomento e as diversas formas de subvenção. Estes mecanismos contribuem para a redução dos custos do investimento inovativo e não prevêem retorno financeiro por parte do beneficiário. No caso dos incentivos fiscais, como mencionado, há o favorecimento das empresas de maior porte, de forma que este tipo de recurso é menos abrangente do que os demais, porém não menos importante.

É por esse motivo que deve haver uma gama de instrumentos disponíveis para o financiamento à inovação, pois cada um tem sua especificidade e alcance mais ou menos restrito. Tal como apontado no estudo da OCDE,

"Num mundo ideal, para o financiamento de um número máximo de projetos factíveis, o sistema de financiamento do investimento relacionado à inovação seria suficientemente elaborado para tornar os vários métodos de financiamento combinados de todas as formas; seria possivel a cada estágio do ciclo do projeto encontrar o 'coquetel' que melhor satisfizesse a estrutura de investimento correspondente e ao grau de incerteza. Informação seria tão completa que cada investidor possuiria todo o conhecimento necessário para julgar o projeto inteiro a partir de seus próprios métodos"(OCDE, 1995:58).

Mesmo sabendo da impossibilidade de se alcançar este mundo ideal, os 
governos vêm se esforçando para garantir a presença de um conjunto de instrumentos visando, com isso, cobrir boa parte da demanda e incentivar empreendimentos inovadores.

"Recursos competitivos, fundos casados, linhas de apoio a centros de excelência, linhas de financiamento de redes e demais arranjos coletivos, financiamento de novas empresas, apoio a pequenas e médias empresas de base tecnológica, apoio à transferência de tecnologia, financiamento de infraestrutura de pesquisa são instrumentos que vêm tendo ênfase em todo o mundo (...)" (MCT/ABC, 2001).

Em resumo, pode-se dizer que adentrar no mundo da inovação significa envolver-se num conjunto maior de incertezas, irreversibilidades, buscar acesso a ativos intangíveis, dentre outros aspectos que dão a esta atividade uma condição muito distinta daquela que permeia os investimentos convencionais. O mercado de capitais, assim como o capital de risco, os incentivos fiscais e outras fontes de recursos públicos acessíveis ao setor privado, e o auto financiamento por parte das grandes empresas, são os principais mecanismos de financiamento capazes de canalizar recursos para a atividade de inovação, mas tendem a atuar em momentos distintos dos investimentos.

Se fatores de natureza macro e microeconômica como taxas de juros, quadro inflacionário, dívida do Estado, incertezas e retorno esperado afetam um possível ajuste entre a oferta e demanda por recursos financeiros, quando se trata de inovações tecnológicas, compatibilizar a oferta e a demanda financeira é algo ainda mais complexo pelos motivos acima mencionados, principalmente na ausência de apoio do setor público. Essas dificuldades, em economias com cenário macroeconômico marcado por desajustes em todas ou quase todas as variáveis destacadas, são ainda mais acentuadas.

\section{Conclusão}

Em Teoria Geral do Emprego do Juro da Moeda, Keynes fez uma proposta seminal sobre a relação de determinação entre investimento produtivo e poupança. Com base nesta determinação, Keynes revela que o crédito bancário 
não apresenta relação direta com a capacidade de poupança existente, desmistificando assim a idéia de que os investimentos dependem do nível de poupança agregada preexistente. Estes sim são diretamente incentivados pela disponibilidade de crédito do sistema financeiro, ou seja, pela disponibilidade de finance.

No entanto, ao assumir crédito, ou melhor, dívidas iniciais, em geral de curto prazo, de forma a não encarecer muito os custos financeiros do investimento, a empresa necessita de outras fontes que lhe permitam consolidar sua dívida financeira no período que antecede seu fluxo de receitas. Com a produção em andamento, haverá geração de renda adicional, via efeito multiplicador dos investimentos e, portanto, de poupança corrente que deverá ser canalizada para os mercados a fim de gerar fontes de financiamento de longo prazo para as empresas endividadas, ou seja, funding. Da mesma forma, os investimentos passados teriam gerado um estoque de poupança que poderia ser canalizado para a empresa endividada no presente.

Em resumo, se houver disponibilidade de crédito por parte dos bancos e propensão a investir por parte dos capitalistas, os investimentos poderão se concretizar. Isso quer dizer que, de acordo com o enfoque keynesiano, a decisão de investimento está fortemente atrelada ao financiamento e não tem, ex ante, relação direta com a poupança, como querem os economistas de tradição neoclássica.

A análise keynesiana pressupõe a existência de uma estrutura financeira implícita baseada em um sistema bancário desenvolvido capaz de prover finance para as empresas e em um mercado organizado de ações nos quais são gerados funding, garantindo a consolidação financeira aos investimentos de longo prazo. Esta separação é extremamente importante, pois compreende-se que, para o crédito, não existe a necessidade de se compatibilizar estoque de poupança com o investimento. Ou seja, para que as empresas tenham acesso ao crédito, basta que os bancos tenham disponibilidade de provê-lo. Já o acesso aos mercados depende dessa compatibilização entre poupança e investimento, isto é, dependem da existência de uma compatibilização entre as estruturas ativas e passivas dos agentes.

Conforme ressalta Studart (1999), esta estrutura proposta por Keynes permite associar os problemas relacionados à separação entre as ações de poupar e de investir ao hiato temporal existente entre financiamento e maturação do financiamento e também à incerteza inerente às economias capitalistas. São 
problemas de adiamento de poder de comando (finance) e compatibilização de estruturas ativas e passivas entre agentes deficitários e superavitários (funding).

Ocorre, porém, que a maioria das estruturas financeiras não conta com esses dois sistemas plenamente desenvolvidos. Ao contrário, quase sempre um é predominante ao outro. Daí Zysman (1983) ter classificado essas estruturas em dois sistemas básicos: aquele com base no mercado de capitais e aquele com base no crédito. ${ }^{32}$

O problema é ainda maior nos países nos quais os canais de consolidação financeira não se desenvolveram de forma significativa. Há casos bem-sucedidos como os da Alemanha, em que a ausência destes canais demandou certos tipos de mediação, tais como uma relação mais próxima entre bancos privados e empresas, o que lhe garantiu a acumulação de capital, ou como o caso do Japão, em que o Estado foi bastante ativo, mas há outros em que nem mesmo a criação de bancos de desenvolvimento e o estabelecimento de políticas de crédito seletivo, contribuíram para trazer resultados expressivos em termos da expansão da atividade produtiva e da acumulação, como o Brasil. Nesses casos, houve uma forte desconexão entre os mecanismos financeiros e a atividade produtiva.

No que diz respeito às transformações atuais da atividade financeira decorrentes do processo de abertura econômica e escala mundial, autores da corrente pós-keynesiana têm mostrado que os novos produtos financeiros estão apontando para uma tendência de reorganização dos sistemas em direção aos mercados de capitais. Esses novos produtos trazem consigo algumas vantagens, dentre elas uma maior liquidez aos ativos e a redução de riscos. A expansão dos mercados secundários e de derivativos são exemplos de novos produtos, que ocorrem em mercados desintermediados, nos quais a informação sobre os contratos está disponível (mercados públicos) (Carvalho et al., 2001:244).

Tudo indica que haverá uma reorganização nestes mercados por conta das referidas mudanças nos sistemas financeiros. Isso significa que os bancos tenderão a adentrar nesses novos mercados desintermediados. Esta, no entanto, é ainda uma tendência, pois sua concretização e velocidade dependerão da capacidade dos mercados de se ajustarem às novas demandas.

\footnotetext{
${ }^{32}$ Conforme visto, estes mercados diferenciam-se pela natureza das transações financeiras, pelos prazos, pelos participantes.
} 
O motivo para este deslocamento é, em grande medida, o barateamento dos custos do financiamento, para o tomador, e a possibilidade de saída por parte do investidor. No entanto, há riscos envolvidos nesta mudança de perfil do sistema financeiro, principalmente por conta da maior volatilidade dos mercados de capitais e pelo menor poder de influência que o Estado tem para controlá-lo.

A chamada universalização dos bancos, a desregulamentação financeira e a manifestação dos investidores institucionais são outros movimentos que se verificam no bojo das transformações do sistema financeiro. Destacam-se como principais investidores institucionais, responsáveis pela gestão de um volume significativo de poupança financeira, os fundos de pensão, as companhias seguradoras e os fundos mútuos de investimento.

Acompanha estas mudanças a ampliação das possibilidades de funding a partir dos novos produtos financeiros, com destaque para os mercados secundários e para a securitização, porém nada garantirá o uso desses produtos para a atividade produtiva e inovativa.

Ou seja, a expansão desses mercados secundários para uma gama maior de títulos e ações parece favorecer a função dos mercados de capitais enquanto instrumento de consolidação financeira. Isso porque ampliam as possibilidades dos investidores alocarem os recursos nestes mercados. Nesse sentido, o mercado de capitais poderia ser uma importante fonte de funding para os investimentos inovativos. Inclusive, se aumentadas as possibilidades de consolidação financeira das empresas, deverá haver também uma maior disposição dos agentes produtivos para investir e uma maior confiabilidade por parte dos bancos para viabilizar o finance. Ocorre que o mercado secundário oferece maior liquidez e permite um maior barateamento da obtenção de recursos, mas ele não é relevante do ponto de vista do financiamento, ou seja, é no mercado primário que o tomador realmente obtém os recursos para seu investimento. No mercado secundário, os títulos e ações são renegociados, caso o investidor queira reaver seu capital antes do prazo determinado.

Estas incertezas são ainda mais evidentes em se tratando do financiamento aos investimentos em inovação. Conforme mencionado neste artigo, as necessidades financeiras em cada etapa do empreendimento inovador ou de um projeto de inovação são bem distintas e exigem recursos financeiros diferenciados quanto ao montante, aos prazos e às formas de aporte. 
As principais mudanças que vêm ocorrendo no sistema financeiro, com a emergência de novos produtos, têm trazido vantagens e desvantagens para o relacionamento entre o sistema financeiro e o sistema nacional de inovação (SNI). Dentre as vantagens, pode-se mencionar o abandono gradual de posturas conservadoras de certos segmentos financeiros em favor de outras mais ousadas, dinâmicas e arriscadas e o surgimento de novos processos de securitização, decorrência da rápida expansão do mercado de títulos para áreas nas quais as relações de crédito antes predominavam. Dentre as desvantagens, recursos financeiros mais voláteis têm colocado desafios importantes para os países, principalmente para aqueles que não contam com um mercado financeiro e de capitais expressivo e para os quais o investimento direto externo e um volume de reservas para saldar compromissos financeiros se fazem cruciais.

Em síntese, para a inovação, apesar das significativas mudanças nas ações dos agentes e da emergência dos investidores institucionais, o papel destes no financiamento aos investimentos inovativos continua tímido, concentrando-se mais nas fases de menor incerteza nos projetos. Ainda no caso do capital de risco, mecanismo elaborado para auxiliar empresas nascentes, há uma tendência dos investidores de maior porte em alocar recursos nas fases finais do processo.

Por esse motivo, mesmo países que dispõem de sistemas financeiros apoiados em mercados de capitais bem estruturados, e com os quais as empresas podem contar para seus investimentos em inovação, não se limitam a este sistema, contando um pesado funding público para apoiar os investimentos em projetos inovativos.

Conforme apresentado neste artigo, além de aportar recursos diretos (por exemplo, atuar como acionista com recursos provenientes de impostos agindo em defesa dos interesses do contribuinte), os governos podem assumir riscos rejeitados pelo mercado, oferecer garantias de empréstimos, assumir parte do risco do investidor, subsidiar ou reduzir as taxas de juros e influenciar o modo pelo qual os investidores privados percebem o risco por meio de parceria públicoprivada (OCDE, 1995). Com estas ações serão ampliadas, e muito, as chances de deslocamento dos recursos financeiros em favor das atividades produtivas e inovativas. 


\section{Referências bibliográficas}

Baer, M., O Rumo Perdido: a crise fiscal e financeira do Estado brasileiro, RJ: Paz e Terra, 213 p., 1993.

Bastos, V.D., "Fundos públicos para ciência e tecnologia", Revista do BNDES, Rio de Janeiro, v.10, n.20, p.229-260, dez., 2003.

Brito Cruz, C.H., "A universidade, a empresa e a pesquisa que o país precisa", Parcerias Estratégicas, n.3, p.5-30, maio, 2000.

Carvalho, C.E., O Que Todo Cidadão Precisa Saber Sobre Mercado Financeiro, SP/ RJ: Global Editora e Distribuidora, 1986.

Carvalho, F.J.C.; Souza, F.E.P.; Sicsú, J., Economia Monetária e Financeira: teoria e politica, Rio de Janeiro: Campus, 2001.

Costa, F.N., Economia Monetária e Financeira: uma abordagem pluralista, São Paulo: Makron Books, 1999.

Cunha, P.H.F. "Perspectivas de reestruturação das políticas de financiamento do desenvolvimento da tecnologia no Brasil”. Relatório (Versão Preliminar), Projeto "Perspectivas de reestruturação das políticas de financiamento do desenvolvimento da tecnologia no Brasil". SP: Fundap, 25 p., 2002

Freitas, M.C.P., "Os fundos de pensão e o financiamento da infra-estrutura", in Rezende, F.; De Paula, T.B. (coords.), Infra-estrutura: perspectivas de reorganização; financiamento, Brasília: IPEA, 1998.

Gorgulho, L.F., "O capital de risco como alternativa de financiamento às pequenas e médias empresas de base tecnológica: o caso do CONTEC/BNDES", Rio de Janeiro: UFRJ, dissertação (Mestrado em Economia), 1996.

Keynes, J.M., Teoria geral do emprego do juro e da moeda. São Paulo: Editora Atlas, 1992.

Macedo e Silva, A.C., Macroeconomia sem Equilíbrio, Rio de Janeiro: Editora Vozes; Campinas: FECAMP, 1999.

MCT/ABC. Ciência, tecnologia e inovação: desafio para a sociedade brasileira - 
LIVRO VERDE/ Coordenado por Cylon Gonçalves da Silva e Lucia Carvalho Pinto de Melo, Brasília: MCT/ABC, 2001.

Mendonça de Barros, J.R. (coord.) et al., Desafios e Oportunidades para o Mercado de Capitais Brasileiro, São Paulo: BOVESPA, jun., 2000 (Estudos para o Desenvolvimento do Mercado de Capitais).

Nóbrega, M. da; Loyola, G.; Guedes Filho, E.M.; Pasqual, D., O Mercado de Capitais: sua importância para o desenvolvimento e os entraves com que se defronta o Brasil, São Paulo: BOVESPA, maio, 2000 (Estudos para o Desenvolvimento do Mercado de Capitais).

OCDE, National systems for financing innovation, Paris: Head of Publications Service, 1995.

Pinho, M.; Côrtes, M.R.; Fernandes, A.C., "A fragilidade das empresas de base tecnológica em economias periféricas: uma interpretação baseada na experiência brasileira", Ensaios FEE, Porto Alegre, v.3, n.1, p.135-162, 2002.

Rosenberg, N., Perspectives on technology, Londres: Cambridge University Press, 1976.

Sandroni, P., Novíssimo Dicionário de Economia, São Paulo: Editora Best Seller, 1999.

Sarno, P. M., O Comportamento das Instituiçôes Bancárias: implicaçôes para a política monetária, Dissertação (Mestrado em Economia) - Universidade Federal Fluminense, Niterói-RJ, 1993.

Singer, P., Para Entender o Mundo Financeiro, São Paulo: Editora Contexto, 2000.

Studart, R., "O sistema financeiro e o financiamento do crescimento: uma alternativa pós-keynesiana à visão convencional”, in Lima, G.T.; Sicsú, J.; De Paula, L.F. (orgs), Macroeconomia Moderna: Keynes e a economia contemporânea, Rio de Janeiro: Editora Campus, p.151-170, 1999. 